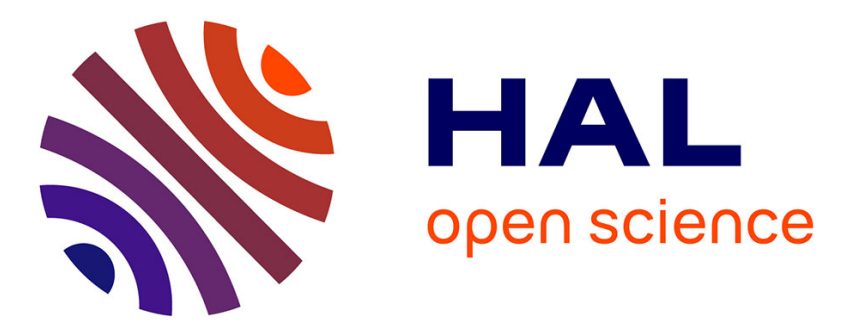

\title{
Plasticity in reproduction and nutrition in wood-boring bivalves (Xylophaga atlantica) from the Mid-Atlantic Ridge
}

Sylvie Marylène Gaudron, T. Haga, H. Wang, S. Laming, S. Duperron

\section{- To cite this version:}

Sylvie Marylène Gaudron, T. Haga, H. Wang, S. Laming, S. Duperron. Plasticity in reproduction and nutrition in wood-boring bivalves (Xylophaga atlantica) from the Mid-Atlantic Ridge. Marine Biology, 2016, 163 (10), pp.213. 10.1007/s00227-016-2988-6 . hal-01383153

\section{HAL Id: hal-01383153 https://hal.sorbonne-universite.fr/hal-01383153}

Submitted on 18 Oct 2016

HAL is a multi-disciplinary open access archive for the deposit and dissemination of scientific research documents, whether they are published or not. The documents may come from teaching and research institutions in France or abroad, or from public or private research centers.
L'archive ouverte pluridisciplinaire HAL, est destinée au dépôt et à la diffusion de documents scientifiques de niveau recherche, publiés ou non, émanant des établissements d'enseignement et de recherche français ou étrangers, des laboratoires publics ou privés. 
1 Plasticity in reproduction and nutrition in wood-boring bivalves (Xylophaga

2 atlantica) from the Mid-Atlantic Ridge

4 Gaudron, $\mathrm{SM}^{1,2^{*}}$, Haga, $\mathrm{T}^{3}$, Wang, $\mathrm{H}^{4}$, Laming, $\mathrm{SR}^{4}$, Duperron, $\mathrm{S}^{4,5}$.

$6 \quad{ }^{1}$ UMR 8187 Laboratoire d'Océanologie et Géosciences (Univ. Lille, CNRS, Univ. Cote d'Opale),

762930 Wimereux, France

$8 \quad{ }^{2}$ Sorbonne Universités, Université Pierre et Marie Curie Paris 06, UFR927, 4 place Jussieu, 75005

9 Paris, France

$10{ }^{3}$ Research Group, Toyohashi Museum of Natural History, 1-238 Oana, Oiwa-chô, Toyohashi, Aichi

11 441- 3147, Japan

$12{ }^{4}$ Sorbonne Universités, Université Pierre et Marie Curie Paris 06, UMR 7208 BOREA (CNRS),

1375052 Paris, France

$14 \quad{ }^{5}$ Institut Universitaire de France, Paris, France

22 * Corresponding author: sylvie.gaudron@upmc.fr

23 Dr Sylvie Marylène Gaudron

24 UMR8187 Laboratoire d'Océanologie et de Géosciences (LOG)

25 Station marine de Wimereux (Université de Lille)

2628 Avenue Foch

27 B.P. 80

2862930 Wimereux (FRANCE)

29 Tel : $0033(0) 321992961$

$30 \quad$ Fax : $0033(0) 321995801$ 


\section{Abstract}

33 High densities of the wood-boring bivalve Xylophaga atlantica colonized pine wood cubes in 34 colonization devices deployed at $2279 \mathrm{~m}$ depth for $414 \mathrm{~d}$ (14 July 2007-31 August 2008) near 35 hydrothermal vents at the Rainbow site on the Mid-Atlantic Ridge ( $\left.36^{\circ} 13.7454^{\prime} \mathrm{N} / 33^{\circ} 54.0513^{\prime} \mathrm{W}\right)$.

36 Histological and biometric observations on specimens with shell lengths (SL) of 0.5-4.2 mm revealed three cohorts in this dioecious population. The first cohort was dominated by mature females, each with an estimated fecundity of $\sim 450$ oocytes with a mean diameter of $28.0 \pm 3.9 \mu \mathrm{m}$ (maximum diameter $40.0 \mu \mathrm{m}$ ); an intermediate cohort was a mix of males and females with SL at

40 first maturity of $\leq 1.7 \mathrm{~mm}$; the third cohort was exclusively morphologically distinct, mature, dwarf 41 males, SL $\sim 500 \mu \mathrm{m}$. These dwarf males were attached to the dorsal shell surfaces of females in the 42 first cohort. The difference in the SL of Prodissochonch I ( 60 $\mu \mathrm{m})$ and Prodissoconch II (500-530 $43 \mu \mathrm{m})$ confirmed planktotrophy. Based on their carbon and nitrogen stable-isotope ratios, and a 44 paedomorphic morphology suggesting they are ill-equipped to bore wood, it seems likely that the dwarf males are heterotrophic filter-feeders. Fluorescence in situ hybridization showed, however, that dwarf males hosted a few Gammaproteobacteria in their gills. The absence of a bacterial signal in the germ cells and developing oocytes of females implies that direct trans-ovarial inheritance of symbiotic bacteria does not occur in $X$. atlantica.

Key-words: colonization, chemosynthetic habitat, bacterial symbiont, food availability, spatial niche, sex determination, growth rate, settlement, paedomorphism, mollusc.

\section{Introduction}

59 The fragmented distribution of highly ephemeral wood-fall habitats in the deep sea (here defined as $60>200 \mathrm{~m}$ depth) depends on the initial introduction of wood into the marine environment (e.g. during 61 extreme weather events), the offshore transport of this wood by oceanographic processes and 62 ultimately, once waterlogged, the deposition of this wood within the deep ocean (Thiel and Gutow 63 2005; Canals et al. 2006; Tyler et al. 2007). Despite a patchy deep-sea distribution, naturally 64 occurring and artificially deployed wood logs are colonized at an astonishing speed by molluscan 
wood-boring bivalves of the family Xylophagaidae (Knudsen 1961; Turner 1973; Voight 2008; Gaudron et al. 2010; Cunha et al. 2013; Romano et al. 2013; Amon et al. 2015). In a pioneering study (Turner 1973), high densities of mature individuals of Xylophaga n. sp. were recorded in wood panels after a short 3-month deployment at $1830 \mathrm{~m}$ in the Northwest Atlantic (39 $\left.46^{\prime} \mathrm{N} / 70^{\circ} 41^{\prime} \mathrm{W}\right)$. This study led her to hypothesize that xylophagaid larvae were abundant, transported by bottom currents and guided by an ability to detect wood over considerable distances, with the capacity to delay metamorphosis in the absence of wood and to settle rapidly following appropriate environmental cues. Culliney and Turner (1976) went on to confirm that pediveligers of X. atlantica (from a shallow water population) in laboratory-based larval studies were indeed able to delay metamorphosis for up to 6 months, indicating a potential to considerably extend the pelagic larval duration (PLD) (see review on PLD, Hilário et al. 2015). Recent short-term colonization experiments (10 d) carried out in the Mediterranean Sea at $1700 \mathrm{~m}$ (Gaudron et al. 2010) and at hydrothermal vents on the Mid-Atlantic Ridge (2275 m, Gaudron unpublished), from which post-larval stages of Xylophaga spp. were recovered, appear to confirm Turner's predictions. Haga and Kase (2013) measured the relative size differences between the post-embryonic and post-settlement larval shells of X. supplicata - i.e. the Prodissoconch I (PdI: $\sim 40 \mu \mathrm{m}$ ) and the Prodissoconch II (PdII: $\sim 310 \mu \mathrm{m}$; shell that is deposited during pelagic larval dispersal) - and found that larvae were planktotrophic for long periods spent in the water column, according to the criteria of Jablonski and Lutz (1983).

Only a few reproductive studies have been carried out on the genus Xylophaga (reviewed by Voight 2015), describing a diversity of reproductive modes. There are contradictory findings for $X$. dorsalis, with evidence for both protandric hermaphroditism (Purchon 1941) and dioecism (Tyler et al. 2007). The latter mode was also identified in X. depalmai where simultaneous hermaphrodites were observed occasionally (Tyler et al. 2007). In Haga and Kase (2013), many (though not all) specimens of $X$. supplicata were identified as protandric, first developing as males and then changing into females after temporary simultaneous hermaphroditism. However, a number of small, paedomorphic specimens attached to the shells of larger females were ultimately found to be dwarf males and not brooded juveniles, as had previously been suggested (Knudsen 1961; Turner 2002).

92 Extrapolating from this misidentification, Haga and Kase (2013) surmised that some or all

93 Xylophaga spp. known to harbor brooded juveniles (19 of the 53 species described), could instead be carrying dwarf males. Using histology, Ockelmann and Dinesen (2011) identified functional dwarf males in Xyloredo ingolfia but misidentified the species according to Haga and Kase (2013), because it was actually Xylophaga clenchi. The relatively frequent occurrences of this phenotype in deep-sea wood-boring species are considered by some authors to be an adaptation to a relative scarcity of wood substrata in deeper waters. 
Wood falls are a locally important input of energy in an otherwise nutrient-depleted deep sea. Various processes contribute to wood-fall degradation. One of these is xylotrophy. Teredinid and xylophagaid families capable of burrowing into wood do so by repeated rotations of their specialized shells which are adorned with rasping denticles (Voight 2015). The wood fragments are then swallowed and stored within a caecum in the foregut of the bivalve (Distel et al. 2011). Though many wood-boring bivalve species are believed to host gill-associated symbionts, only the Gammaproteobacteria (e.g. Teredinibacter turnerae) found in the gills of teredinid shipworms have been well-categorised metabolically (Waterbury et al. 1983; Distel et al. 2002a, b; O'Connor et al. 2014). These Gammaproteobacteria can perform both cellulolysis and fix nitrogen. In the xylophagaids, Distel and Roberts (1998) first identified bacterial symbionts within the gills of Xylophaga atlantica and X. washingtona. Based on 16S rRNA high-throughput sequencing, Fagervold et al. (2014) have since identified bacterial OTUs (Operational Taxonomic Units) within the gills of Xylophaga spp. that resemble those identified in shipworms. However, the exact location of these bacteria within host tissues, their abundance and their activity remain undetermined.

Xylophaga atlantica were collected from 2279 m depth on the Mid-Atlantic Ridge and those

114 found carrying potential dwarf males were investigated. We conducted a comprehensive analysis of

115 their reproduction and nutrition. We tried to answer several questions in this study: 1) Are the

116 biology and ecology of this deep X. atlantica population similar to that described for shallow-water

$117 X$. atlantica? To answer this we examined gametogenesis, fecundity, growth rate, size at first

118 maturity and larval shell dimensions (PdI and II), using histology, scanning electron microscopy and 119 image analysis; 2) What could have driven dwarfism in this X. atlantica population? 3) Being ill120 equipped to bore wood, do dwarf males host symbiotic bacteria in their gills and is there evidence of 121 symbiont assimilation? To test this, we used Fluorescence in situ Hybridization (FISH) to look for 122 bacterial symbionts within gill filaments, and employed stable isotope analyses $\left(\delta^{13} \mathrm{C}\right.$ and $\left.\delta^{15} \mathrm{~N}\right)$ to 123 identify whether xylotrophy might contribute to host nutrition; 4) Is there any evidence for maternal 124 transmission of bacterial symbionts during oogenesis? FISH was applied to reproductive tissues to 125 confirm whether putative bacterial symbionts were present within oocytes at various stages of their 126 development within the female acini.

\section{Materials and methods}

129 Collection and identification

130 Wood-boring bivalves were collected from numerous $2 \mathrm{~cm}$-sided pine wood cubes housed in a single 131 CHEMECOLI (CHEMosynthetic Ecosystem COlonization by Larval Invertebrates) colonization 
132 device which was deployed on 14 July 2007 for 414 d on the Mid-Atlantic Ridge at the Rainbow 133 hydrothermal vent field $\left(36^{\circ} 13.7454^{\prime} \mathrm{N}\right.$ and $\left.33^{\circ} 54.0513^{\prime} \mathrm{W}\right)$, at $2279-\mathrm{m}$ depth near some small vent

134 chimneys (Online resource 1). The device contained 87 cubes for a total wood volume of $1.539 \mathrm{dm}^{3}$.

135 Once on board, cubes were randomly selected from the bottom, middle and top of the device, and

136 fixed in different fixatives in a cold room. Specimens from cubes fixed in $4 \%$ buffered formaldehyde

137 in twice-filtered seawater (TFSW) were used for taxonomy. Specimens from cubes fixed in 95\%

138 ethanol were used for biometry and those frozen at $-20^{\circ} \mathrm{C}$ were used for stable isotope analyses.

139 Specimens from cubes fixed in $4 \%$ buffered formaldehyde in TFSW for $4 \mathrm{~h}$ at $4{ }^{\circ} \mathrm{C}$, rinsed three

140 times in TFSW and then transferred into 50/50 Ethanol/TFSW were used for both Fluorescence in

141 situ hybridization (FISH) and for reproductive histology, following the same protocol as Gaudron et

142 al. (2012). Wood cubes were dissected aseptically with sterile razor blades in order to collect all

143 wood-boring bivalves. Specimens were identified morphologically based on descriptions by Turner

144 (2002).

145 DNA was extracted from 13 large individuals and 15 dwarf males using the QiaQuick

146 Dneasy Kit (Qiagen, USA). Partial sequences of the gene encoding 28S rRNA were amplified by

147 PCR using primers 28S-C1 ACCCGCTGAATTTAAGCAT and 28S-

148 C2TGAACTCTCTCTTCAAAGTTCTTTTC, as described in Williams et al. (2004). Sequences were

149 compared with GenBank using the Blast tool (Altschul 1997) and deposited to GenBank with

150 accession KU684449 (one larger specimen) and KU684450 (one dwarf male).

152 Haematoxylin / Eosin staining and Fluorescence in situ Hybridization (FISH)

153 A total of 16 Xylophaga atlantica (Online resource 1) of various sizes (1.7-4.2 mm shell lengths,

154 SL) from the smallest to the largest individuals identified from sorting (except dwarf males) were

155 measured using an Olympus SZX12 binocular equipped with SPOT software before being dissected.

156 Tissues were rinsed in butan-1-ol and Histoclear (Euromedex Ltd.) and embedded in Paraffin

157 Embedding Wax (melting point $52^{\circ} \mathrm{C}$ ). The soft tissues (bivalves without shell) were cut into $8 \mu \mathrm{m}$ -

158 thick sections using a microtome (Microtome Finesse 325, Thermo Fisher Scientific) and deposited

159 on SuperFrost Plus slides (Euromedex Ltd.). A standard haematoxylin/eosin (HE) staining protocol

160 (Gaudron et al. 2012) was used on one in every ten slides and observations were performed using an

161 Olympus BX61 light microscope (Olympus, Japan) equipped with ImagePro software. The sex was

162 identified in these 16 specimens. Oocyte diameters were measured in 7 female specimens and partial

163 fecundity was estimated by counting the total number of fully-grown oocytes within all acini seen in

164 histological sections of four females. 
Potential dwarf males (SL $<500 \mu \mathrm{m}, n=5$ ) were blotted dry and infiltrated ( $8 \times 30$-min

infiltrations) in a gelatine capsule (size 00, Electron Microscopy Sciences, UK) filled with LR-White resin (London Resin Company, UK), transferred to a fresh resin-filled gelatine capsule, orientated appropriately, capped, and polymerised at $55^{\circ} \mathrm{C}(20 \mathrm{~h}$ minimum). Gelatine was then removed with hand-hot water. Resin blocks were wet-sectioned (glass knife) on a Leica EM Ultra Cut R Ultramicrotome (Germany) to thicknesses of $350 \mathrm{~nm}-1 \mu \mathrm{m}$, deposited on Superfrost-plus slides, and stained in Toluidine Blue while others were unstained for FISH.

FISH was employed on the non-stained slides of both large specimens and potential dwarf males to reveal the presence of possible symbiotic bacteria in gills and female gametes following the protocol of Gaudron et al. (2012). Due to the small size of the bivalves, a cross-section of the entire individual, including the digestive tract, acini with gametes, and the gill could be visualized on most slides. The paraffin wax was removed using a serial gradient of ethanol and Histoclear prior to FISH. The LR-White slide-mounted sections were only rehydrated in phosphate buffered saline (PBS 1x). FISH was performed using Cy3- and Cy5-labeled probes as described previously (Duperron et al. 2005 ) with a hybridization buffer containing $30 \%$ formamide. Probes Gam-42 (5'GCCTTCCCACATCGTTT-3'; Manz et al. 1992), targeting the 16S rRNA (small subunit) of most Gammaproteobacteria, EUB-338 targeting most Eubacteria (5'-GCTGCCTCCCGTAGGAGT-3'; Amann et al. 1990) and NON-338, a control for non-specific binding (5'ACTCCTACGGGAGGCAGC-3'; Wallner et al. 1993) were used. After washing, slides were mounted in Slow-Fade Gold (Invitrogen) containing DAPI, which stains nucleic acids. Fluorescence

Size-distribution, bivalve density and growth rate

SLs of 100 large borers and 68 dwarf males were measured with an Olympus SZX12 binocular microscope equipped with SPOT software. The protocol followed that of Romano et al. (2013), using the Bhattacharya method and the specific routine in FISAT II package (FAO 2002) to identify each Xylophaga atlantica cohort that recruited into the CHEMECOLI during the 414-d deployment. SL frequency distributions in 0.25 -mm SL intervals were used to accommodate all individuals in this population, including the dwarf males.

The relative density of individuals was estimated by counting the number of wood-borers recovered from a stratified, random subsample of 15 cubes from the top, middle and bottom of the CHEMECOLI ( 5 cubes zone ${ }^{-1}$ ). Minimal mean growth rate was estimated by subtracting the mean SL of PdII from the computed mean SL of the first cohort from FISAT II, dividing the result by the number of days of deployment, minus $10 \mathrm{~d}(404 \mathrm{~d})$; post-larval stages of $X$. atlantica had already 
colonized an identical, short-term, 10-d deployment (Gaudron unpublished data) at the same site (Rainbow 2275m; $36^{\circ} 13.7553 \mathrm{~N}$ and $33^{\circ} 54.11 \mathrm{~W}$ ).SLs of PdII were measured in randomly selected individuals $(n=5)$ in each cohort. Mean SL for each cohort were compared using a student test (MINITAB v.15).

204 Stable isotope analyses

205 Frozen wood-boring bivalve females $(n=3)$ bearing dwarf males (pool of 30 individuals) were 206 identified under a dissecting microscope and dissected to remove the shell when possible. Frozen wood cubes $(n=3)$ from CHEMECOLI were first sliced into pieces with a sterile scalpel, then rinsed in distilled water, and finally screened under a dissecting microscope to check for the presence of metazoan material (tissue, faeces, eggs and larvae). Of these, bivalve tissues (autonomous and dwarf males), pieces of wood and one amphinomid polychaete (control) were rinsed in distilled water and then dried $\left(2 \mathrm{~d}, 60{ }^{\circ} \mathrm{C}\right)$. Some dried subsamples of female wood-borer tissues and a pool of whole dwarf males were treated with $1 \mathrm{~N} \mathrm{HCL}(\sim 3 \mathrm{~h})$ to remove inorganic carbon and then rinsed with distilled water.

$1 \mathrm{mg}( \pm 0.1 \mathrm{mg})$ of dried bivalve, polychaete tissues or wood pieces were analysed using a CHN elemental analyser (EuroVector, Milan, Italy) for particulate organic carbon (POC) and particulate nitrogen $(\mathrm{PN})$ in order to calculate their $\mathrm{C} / \mathrm{N}$ atomic ratio (Cat/Nat). The resultant gas from the elemental analysis was introduced into a GV IsoPrime (UK) stable isotope mass spectrometer at Iso-Analytical (Crewe, UK). Values of $\delta^{13} \mathrm{C}$ and $\delta^{15} \mathrm{~N}$ were determined and expressed as relative per-mil (\%) differences between samples and Pee Dee Belemnite (PDB) for carbon and air for nitrogen according to the following equation:

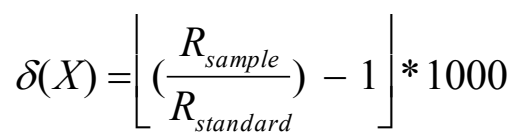
where $X(\%)$ is ${ }^{13} \mathrm{C}$ and ${ }^{15} \mathrm{~N}$ abundance and $R$ is the ${ }^{13} \mathrm{C} /{ }^{12} \mathrm{C}$ and ${ }^{15} \mathrm{~N} /{ }^{14} \mathrm{~N}$ ratios.

\section{Scanning Electron Microscopy (SEM)}

The dwarf males and the autonomous wood-boring females were dehydrated using an ethanol series and critical-point dried, then coated with gold before observations with a SEM (Cambridge S260 at $15 \mathrm{kV}$ ). PdI was observed and measured. The internal anatomy of a dwarf male was observed.

\section{Results}


231 Identification of wood borers was based on taxonomically-relevant features of the inhalant and

232 exhalant siphons, the shape of the mesoplax (Online resource 1) and the posterior adductor scar,

233 which all matched the description of Xylophaga atlantica (Turner 2002). The 28S rRNA partial

234 sequences of all specimens (including putative dwarf males, see Fig. 1b, c) were identical (base to

235 base). Compared with GenBank, each returned sequences with $98 \%$ similarity scores to five $28 \mathrm{~S}$

236 rRNA sequences attributed to Xylophaga atlantica deposited by Romano et al. (2014). Figure 1b

237 shows dwarf males attached ventrally by the byssus threads on the dorsal side of an autonomous

238 female (Online resource 2). Dwarf males did not have the denticles on their shells needed to bore

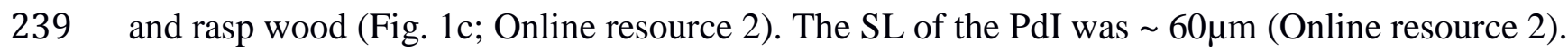

240 Dwarf males had mature spermatozoa (Online resource 2). No dissoconch deposition (adult shell)

241 was observed in dwarf males, despite the presence of mature spermatozoa and a ligament, which

242 indicated that metamorphosis into adults had occurred (Online resource 2). Thus dwarf male SL, 540

$243 \pm 2.2 \mu \mathrm{m}(n=68)$, essentially represented their SL at settlement (i.e. PdII).

245 Size structure of the population

246 The SL frequency distributions were trimodal (Online resource 3), but there were only two true

247 cohorts since dwarf males lacked adult dissoconch shell despite being sexually mature (Online

248 resource 2). The cohort with the individuals with the greatest SL $(3.4 \pm 0.5 \mathrm{~mm})$ were mostly large

249 females bearing dwarf males (Online resource 3), and the eight specimens in this size range used in

250 histology were all females (Fig. 2). The intermediate cohort (Online resource 3) had a mean SL of

$2512.6 \pm 0.4 \mathrm{~mm}$ : the sex ratio for the eight specimens used in histology in this size range was 1:1 (Fig.

252 3). The remaining cohort with the smallest SLs had a mean SL of $0.6 \pm 0.1 \mathrm{~mm}$, and was composed

253 exclusively of dwarf males examined using both SEM (Online resource 2) and histology (Fig. 4).

254 The density of all Xylophaga atlantica (including dwarf males) was estimated at 6853 individuals

$255 \mathrm{dm}^{-3}$. The minimal shell growth rate was estimated at $7 \mu \mathrm{m} \mathrm{d}^{-1}$ for the first cohort (Online resource

256 4). Mean SL of PdII for the three cohorts were not significantly different using a $t$-test (Cohort 1: 500

$257 \pm 10 \mu \mathrm{m}$; Cohort 2: $530 \pm 30 \mu \mathrm{m}$; cohort 3: $530 \pm 30 \mu \mathrm{m})$.

259 Gametogenesis, fecundity, size at first maturity and spawning behaviour

260 All specimens examined using SEM or HE staining of histological sections had mature gametes, so 261 no immature specimens were observed. Wood-boring females $(n=12)$ carrying mature oocytes were

262 1.7-4.2 mm SL. Non-dwarf wood-boring males $(n=4)$ and dwarf males, both carried all stages of 263 gametes (spermatogonia to mature spermatozoids), and were 1.7-2.3 mm SL and 0.48-0.58 mm SL 264 respectively. Partial fecundity was estimated at $450 \pm 130$ oocytes female ${ }^{-1}(n=4)$. Mean oocyte 
diameter was $28.0 \pm 3.9 \mu \mathrm{m}(n=7)$ for mature females in the first cohort (Fig. 2a, c) with a maximum diameter of $40 \mu \mathrm{m}$. A few mature oocytes in Prophase I (unfertilized), similar to those of the first-cohort wood-boring females, were found in the gill chambers of two second-cohort males (Fig. 2a, c). These spawned oocytes were probably captured following their release by a female, suggesting that spawning was occurring when the colonization device was retrieved. There was no evidence of hermaphroditism.

Symbiotic bacteria

273 In females and non-dwarf males, gill filaments were occupied by dense populations of symbiotic 274 bacteria in gill cells devoid of cilia (Fig. 2b, d; Fig. 3b). Depending on sectioning angle and region 275 (see HE sections [Fig. 3c; Fig. 3a]), the abundance of ciliated versus bacterium-loaded gill epithelial 276 cells varied but no quantification was attempted. Signals from the Gammaproteobacteria- and the 277 Eubacteria-targeting probes almost fully overlapped in both sexes, indicating that gill-associated bacteria were predominantly Gammaproteobacteria. Histological sections of female gametes at different stages of oogenesis were available, their nuclei stained with DAPI (Fig. 2b). Germ cells gave strong DAPI blue signals (as did the nuclei of gill-filament epithelial cells), allowing the boundaries of acini to be discerned, within which fully-grown vitellogenic oocytes were packed (Fig. 2a). No bacterial signal was ever found on, or inside germ cells and fully-grown vitellogenic oocytes, where the unambiguous bacterial signal in gill tissue served as a positive control (Fig. 2b). Bacteria are therefore believed to be absent from reproductive tissues in these $X$. atlantica.

In dwarf males, gill filaments were less numerous and much smaller (Fig. 4b). Nevertheless, unambiguous Gammaproteobacteria FISH signals were detected in association with the non-ciliated abfrontal regions of gill filaments (white arrow in Fig. 4c). Visually, bacterial densities were lower than those in larger specimens. Bacteria appeared to be extracellular, but higher resolution would be needed to confirm this.

Wood-based diet and trophic level

292 Stable isotope analyses performed on female wood-borers yielded $\delta^{13} \mathrm{C}$ values of $\sim 22 \%$ close to the

$293 \delta^{13} \mathrm{C}$ values of the wood itself $\left(\sim 23 \%\right.$ ) (Table 1). Dwarf male tissues were more enriched in ${ }^{13} \mathrm{C}$ 294 ( 20\%), resembling values obtained for the amphinomid polychaete control (Table 1). Despite the paucity of nitrogen within the wood itself ( $\mathrm{C} / \mathrm{N} \sim 160$; Table 1) $\mathrm{C} / \mathrm{N}$ values of the overall fauna were 3-5 (Table 1). The $\delta^{15} \mathrm{~N}$ values ( 4\%o; Table 1$)$ of the females were just at the upper limit of primary producers in food webs (Minagawa and Wada 1984$)$, while $\delta^{15} \mathrm{~N}$ values $(\sim 6.5 \%$; Table 1$)$ of 
299 (Minagawa and Wada 1984). For comparison, amphinomid polychaetes, usually seen as predators, 300 had $\delta^{15} \mathrm{~N}$ values of $\sim 8 \%$ (Table 1 ). This reflects the lowest limit for secondary consumers within 301 food webs (Minagawa and Wada 1984).

\section{Discussion}

304 Wood-boring bivalve specimens in this study were identified as Xylophaga atlantica Richards 1942 305 based on morphology (Turner 2002) and 28S rRNA sequences with a 98\% similarity to sequences of $306 X$. atlantica in Genbank. The 28S rRNA sequences of large females in the present study matched 307 (100\% similarity) with 28S rRNA sequences of dwarf males, which confirms that individuals belong 308 to the same species. Xylophaga atlantica has previously been collected in the Western Atlantic at 309 depths of 15-1242 m (Turner 2002) and more recently, X. atlantica ('morphotypes C, D and E') was 310 collected from 900-2000 $\mathrm{m}$ in the Western Mediterranean Sea and Eastern Atlantic (Romano et al.

3112013 ; 2014; Online resource 4). However, none of these studies reported the presence of dwarf 312 males. One may wonder what could have induced this phenotypic plasticity in morphology and 313 reproductive strategy.

315 Traits of Xylophaga atlantica from deep and shallow populations

316 Specimens of $X$. atlantica in the current study were gonochoristic; there was no evidence of sex 317 change through a hermaphroditic phase. The mature oocytes $(\sim 40 \mu \mathrm{m})$ in this study are very similar 318 to those of a shallow population of X. atlantica (45 $\mu \mathrm{m}$, Culliney and Turner 1976). Large females

319 and their associated dwarf males both carried mature gametes, while spawned oocytes were observed 320 within the pallial cavity of non-dwarf males and female specimens. This could indicate spawning 321 synchronicity within this xylophagaid population at the time of sampling (end of August 2008), and 322 suggests that some instances of fertilization might occur within the pallial cavity of one, or the other 323 parent. At the end of the 414-d deployment three cohorts of veligers had recruited (or two, if we 324 exclude dwarf males). Shallow-water $X$. atlantica has been shown to recruit seasonally (Berg et al. 325 1987). Culliney and Turner (1976) found ripe $X$. atlantica in late summer, and suggested 326 metamorphosis and settlement occurred from autumn to winter. Our data cannot detect whether 327 seasonality played a role in structuring size-frequency distributions in the MAR population.

$328 \quad$ Fecundity and size (age) at first maturity in xylophagaids have only been recorded previously 329 in X. depalmai from colonization devices deployed at $500 \mathrm{~m}$ (Tyler et al. 2007; Online resource 4). 330 In that study, fecundity was stated to be 'high' but no data were provided. Gametogenesis was 331 already occurring in specimens collected from 59-d colonization experiments, with size at first 
332 maturity $>2 \mathrm{~mm}$ SL (Tyler et al. 2007; Table 1). In the present study, the size at first maturity was $\leq$ $3331.7 \mathrm{~mm}$ SL for non-dwarf males and females (Online resource 4). Dwarf males had SL at first 334 maturity of $\leq 0.5 \mathrm{~mm}$ almost immediately after settlement. It is difficult to classify the fecundity as 335 low, moderate, or high in this study ( 450 oocytesfemale $\left.{ }^{-1}\right)$, given the paucity of other data.

336 Fecundity in the opportunistic gastropod Cocculina rathnuni, colonizing deep-sea wood substrates,

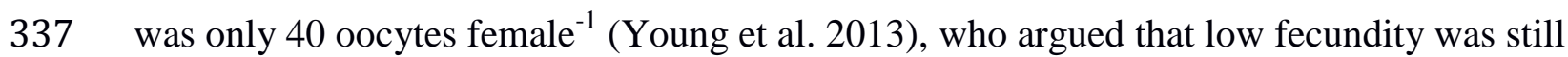
338 compatible with opportunism, as larval predation pressure in the deep sea is likely less than in 339 shallow water. It is not clear whether this is true for larvae arriving at reducing habitats, such as 340 sunken wood, where faunal densities are much higher. However, only one specimen of a wood-fall 341 species known to feed on xylophagaid larvae (Ockelmann and Dinesen 2011) was collected from the 342 CHEMECOLI (see Rodrigues et al. 2015), the small larvivorous mussel Idas argenteus. Wood-fall 343 habitats are highly ephemeral. Tyler et al. (2007) argued that biological traits such as the early 344 reproductive development of $X$. depalmai, typically rare in deep-sea organisms, may represent 345 adaptations to ephemeral reducing habitats (e.g. hydrothermal vents, whale falls and wood falls).

346 Similar hypotheses have since been proposed for other molluscs that colonize wood, which are also 347 small at first maturity. These include the bathymodiolin mussels Idas modiolaeformis (2.35 mm SL, 348 Laming et al. 2014) and I. simpsoni (1.8 mm SL, Génio et al. 2015), and several wood-colonizing 349 limpet species (e.g. Cocculina rathbuni: $<1.5 \mathrm{~mm}$ SL, Young et al. 2013).

In our study, the estimated growth rate of $X$. atlantica $\left(7 \mu \mathrm{m} \mathrm{d}^{-1}\right)$ was relatively low when compared with previous wood colonization experiments (Online resource 4). This may reflect spatial constraints imposed by the high densities of individuals collected in a low temperature habitat.

353 Physical crowding has been proposed as contributing to unexpectedly low growth rates in shallow354 water X. atlantica (Romey et al. 1994; Online resource 4) and in deep-water, dense populations of $X$. 355 alexisi (Voight and Segonzac 2012; Online resource 4). These authors argued that at low population 356 densities, $X$. alexisi might have much higher potential growth rates.

358 Larval biology of a deep Xylophaga atlantica population

359 The SL of the PdII for the three cohorts $(\sim 500-530 \mu \mathrm{m})$, and the small post-embryonic PdI of the 360 earliest veliger ( $\mathrm{SL} \sim 60 \mu \mathrm{m}$ ), provide insights into the planktotrophic larval mode and its duration 361 (Jablonski and Lutz 1983).The size of the PdII measured in this study is nearly twice that recorded 362 for larvae of laboratory-reared, shallow-water X. atlantica (Culliney and Turner 1976).This suggests 363 that veligers of the wood-borers recovered within CHEMECOLIs at $2279 \mathrm{~m}$, have probably spent an 364 extended period of time in the water column. Such extended periods may be an adaptation to very 365 fragmented habitat distributions. This hypothesis was proposed for X. alexisi larvae from an abyssal- 
plain population $(4626 \mathrm{~m}$ ) as a means of surviving long periods in the plankton (Voight and

Segonzac 2012). The relatively cool $\left(\sim 4^{\circ} \mathrm{C}\right)$ water temperature in the deep Atlantic Ocean may lengthen PLDs, as lower temperatures are likely to induce lower metabolic rates.

PdII SLs in X. atlantica mirror sizes recorded previously in the cold-seep bathymodiolin mussels Idas modiolaeformis and 'Bathymodiolus' childressi, where PLDs of up to 5 and 13 months respectively have been demonstrated (Gaudron et al. 2012; Arellano et al. 2014). Under favourable oceanographic transport conditions, extended PLD could explain the broad geographical distribution of $X$. atlantica, spanning the Eastern Atlantic, into the Western Atlantic, and to the Western Mediterranean (Romano et al. 2014). Xylophaga atlantica may thus be considered an amphi-Atlantic candidate species with a potential for long-distance dispersal comparable to that documented in some Bathymodiolus species (Olu et al. 2010).

\section{Epigenetic factors influencing sex-determination in Xylophaga atlantica?}

The existence of large females and dwarf males in $X$. atlantica suggests a kind of epigenetic sexdetermination in this species, rather than complete genetic sex regulation. There may be environmental drivers similar those in other metazoans, such as food availability, population density and temperature (e.g. Santerre et al. 2013). In the present study, two epigenetic or 'proximate' factors may apply: food availability and the diminution of the spatial niche. Consider the following scenario: at the beginning of the colonization experiment in 2007, deployed wood represented nascent habitat for settling wood-borer larvae, where optimal food availability favoured a female bias in the sexratio (first cohort) as seen in other bivalves where oogenesis requires a considerable energy investment (Chávez-Villalba et al. 2011). During the course of the 414-d deployment, the wood was progressively consumed by this first cohort so food and space availability decreased with time. New colonists that arrived and settled (second and third cohorts) shifted the population towards a male bias, spermatogenesis having a lower metabolic demand (Chávez-Villalba et al. 2011). In this scenario, the initial epigenetic factor driving sex-determination is food availability, favouring females. The second, a smaller spatial niche, selects for non-dwarf males and ultimately, dwarfism with larvae settling directly on female shells. Romano et al. (2014) did not find dwarf males in their samples of $X$. atlantica. However, their colonization experiments used pieces of wood ten times bigger than those in the current study, with wood-borer densities 60 times lower than those described here, so there were no constraints on food or space.

Male dwarfism has evolved in species with small population sizes and in which the female is sedentary or hard to find, such as the echiurian, Bonellia viridis (Berec et al. 2005). Haga and Kase (2013) recorded a similar trend in wood-associated $X$. supplicata with low population densities, 
where the direct association of females with dwarf males would increase fertilisation success, while dwarfism was argued to compensate for a rarity of wood logs (resource limiting). Voight (2015) pointed out that dwarf males offer a dioecious strategy that minimizes crowding and resource consumption. In the opportunistic polychaete, Osedax spp., which colonize decomposing whale carcasses (another sulfidic deep-sea organic-fall habitat), most males are dwarves with a high density of female bone-eating worms (Rouse et al. 2004). Occurrence of dwarf males in X. atlantica and Osedax spp. seems to be a convergence that may reflect similar evolutionary constraints acting on these species in habitats that share many characteristics (ephemeral existence, patchiness, rarity, but

410 Xylotrophy and symbiosis in wood-boring adults versus associated dwarf males of Xylophaga 411 atlantica

412 Xylotrophy was examined in shallow-water X. atlantica (recovered from oak in lobster traps at 100413 m depth in the Western Atlantic), but it is not clear whether Gammaproteobacteria in the gills of 414 Xylophaga spp. play any role in cellulolytic (synthesis of cellulase enzyme) or/and nitrogen-fixing 415 activities (Distel and Roberts 1997). In our study, the shape and sculpture of xylophagaid shells (e.g. 416 such as in cohorts 1 and 2) allows them to physically bore wood, with the potential to assimilate the 417 pulp with the aid of hypothesized cellulolytic symbiotic bacteria (metazoans are rarely able to 418 produce cellulase). Stable isotope values suggest that large specimens ( $1^{\text {st }}$ cohort) had a diet based on 419 direct wood consumption, with $\sim 1 \%$ fractionation (DeNiro and Epstein 1978) of the ${ }^{13} \mathrm{C}$ between 420 the wood and bivalve tissues. The $\mathrm{C} / \mathrm{N}(\sim 160)$ of the wood is a consequence of low nitrogen levels, a 421 feature common to most sunken-wood habitats (Nishimoto et al. 2009; Duperron et al. 2013). That means that xylotrophic metazoans need a separate source of nitrogen, and symbiosis with nitrogen-

423 fixing bacteria may be one alternative. Gammaproteobacteria were very abundant in the gills of large

$424 X$. atlantica specimens in this study but were rare by comparison in the gills of dwarf males. To date, 425 the role of these putative gill bacterial symbionts in both dwarf males and full-sized specimens has 426 yet to be confirmed.

Stable carbon isotopes $(\sim 20 \%$ ) recorded in the dwarf males did not reflect the consumption of wood in the current study. $\delta^{15} \mathrm{~N}$ ratios (Table 1) were more in line with the levels of primary consumers in a classical food web and much higher than those of large specimens (Minagawa and 430 Wada 1984). Fagervold et al. (2014) described specific bacterial communities found in association 431 with the faecal pellets of Xylophaga spp., which accumulate within their burrows. Given the high 432 densities of $X$. atlantica in this study, it is likely that the resulting faecal matter and by-products 433 generated through burrowing would have formed a component of the dwarf males' diet. Thus, not 
434 only do the dwarf males retain paedomorphic traits, but they are likely predominantly heterotrophic

435 filter-feeders. Unfortunately stable isotope analyses in the current study did not include the

436 associated detritus, so the exact source of nutrition in dwarf males cannot be confirmed.

438 Bacterial transmission in Xylophaga atlantica

439 The absence of Gammaproteobacteria in oocytes suggests that bacterial symbionts of $X$. atlantica are 440 not transmitted directly from the parent organism during gametogenesis or prior to spawning. The 441 presence of a low number of bacteria in dwarf males measuring $500 \mu \mathrm{m}$ SL indicates that symbiont 442 acquisition had already occurred at this stage in this sex-related phenotype. Since shell development 443 following metamorphosis cannot be defined, it remains unclear whether acquisition occurred prior to, 444 during, or after settlement, as reported for some Bathymodiolinae mussels (Laming et al. 2014; 445 2015). The potential for horizontal bacterial transmission may be supported by recent 454446 pyrosequencing analyses of the bacterial communities associated with our pine wood cubes, which 447 identified close relatives of shipworm symbionts (Szafranski et al. 2015). It is possible that free448 living forms of these symbionts (or the same symbionts living in other proximal hosts) may be 449 acquired directly from the environment. Although it is possible that mature oocytes acquire bacteria 450 while entrained within the bacteria-loaded gill filaments of females and large males (i.e. before or 451 around the time of fertilization), no bacteria were found attached to oocytes in the pallial cavity of 452 specimens from the current study.

\section{Conclusion}

455 Here we have presented evidence that higher population density in Xylophaga atlantica may be 456 accompanied by shifts in reproductive mode, probably in response to epigenetic influences. Rapid 457 settlement, moderate fecundity and small size at first maturity may be adaptations to the ephemeral 458 and patchy nature of wood-fall habitats, while male dwarfism, an extreme form of sexual 459 dimorphism, is believed to be an adaptation to the inherently finite nutritional and spatial resources 460 available. The apparent disparity between PLDs of shallow- and deep-water X. atlantica likely 461 relates to the relative paucity of suitable habitats in the deep sea leading to long larval dispersal. The 462 small sizes and different nutrition of dwarf males permit the opportunistic use of a unique spatial 463 niche. This adaptation allows $X$. atlantica populations to persist through resource partitioning, 464 despite their finite availability. Regarding symbiosis we confirm that large specimens of $X$. atlantica 465 host Gammaproteobacteria within their gills but with no occurrence in germ lines, which likely rules 
466 out trans-ovarial inheritance, suggesting environmental bacterial transmission is the principal mode

467 for symbiont transmission.

\section{Acknowledgements}

470 Authors would like to thank the people who have deployed and recovered the CHEMECOLIs:

471 Delphine Cottin and Amandine Nunes Jorge. We are grateful to chief scientists, captains and crews 472 of RVs Pourquoi pas? and L'Atalante, and teams operating ROVs Victor 6000 (Ifremer, France) and 473 submersible Nautile (Ifremer, France) during the cruises MOMARDREAM-07 and

474 MOMARDEAM-08. Sample collection and construction of the CHEMECOLIs were funded by 475 CHEMECO (European Sciences Foundation (ESF)/Eurocores/EURODEEP/0001/2007). Analyses 476 and interpretation of data were supported by HERMIONE European Commission (FP7/2007-2013$477 \mathrm{n}^{\circ}$ 226354), University of Pierre and Marie Curie and Institut Universitaire de France. S. Laming 478 was co-funded by a MARES PhD grant (FPA2011-0016), a post-doctoral grant HERMIONE EC 479 (FP7/2007-2013-n $\left.{ }^{\circ} 226354\right)$. T. Haga was partially funded by a Grant-in-Aid for JSPS fellows 480 (\#198300 and \#237855). We would like to thank C. Romano for interesting scientific exchanges on 481 the biology and ecology of wood-boring bivalves. We would like to thank J. Voight on scientific 482 exchanges regarding taxonomy. We would like to thank also V. Bazin (IFR83, UPMC) for a great 483 experience with the scanning electron microscopy, N. Léger for her help with some of the 484 preparation of in situ hybridization, and C. Rodrigues for running the PCRs and the two molecular 485 sequence analyses.

\section{Compliance with Ethical Standards}

488 This study was funded by both European Sciences Foundation (ESF)/Eurocores/EURODEEP/0001/2007) and by HERMIONE European Commission (FP7/2007-2013-n $\left.{ }^{\circ} 226354\right)$. All authors declare that they have no conflict of interest. All applicable international, national, and/or institutional guidelines for the care and use of animals were followed. 
501 Amann R, Krumholz L, Stahl D (1990) Fluorescent-oligonucleotide probing of whole cells for

502 determinative, phylogenetic, and environmental-studies in microbiology. J Bacteriol 172: 762-770 503

504 Amon DJ, Sykes D, Ahmed F, Copley JT, Kemp KM, Tyler PA, Young, CM, Glover, AG (2015)

505 Burrow forms, growth rates and feeding rates of wood-boring Xylophagaidae bivalves revealed by 506 micro-computed tomography. Front Mar Sci. doi: 10.3389/fmars.2015.00010

508 Arellano SM, Gaest ALV, Johnson SB, Vrijenhoek RC, Young CM (2014) Larvae from deep-sea 509 methane seeps disperse in surface waters. Proc R Soc B 281: 20133276.

510 doi.org/10.1098/rspb.2013.3276

512 Altschul SF, Madden TL, Schäffer AA, Zhang J, Zhang Z, Miller W et al (1997) Gapped BLAST

513 andPSI-BLAST: a new generation of protein database search programs. Nucl Acids Res 25: 3389 5143402

515

516 Berec L, Schembri PJ, Boukal DS (2005) Sex determination in Bonellia viridis (Echiura:

517 Bonelliidae): population dynamics and evolution. Oikos 108: 473-484

519 Berg C, Early J, Butman B, Turner R (1987) Seasonal recruitment of marine invertebrates to hard 520 substrates on Georges Bank and the eastern continental-shelf of the United-States. The Nautilus 101: $521 \quad 19-24$

522

523 Bienhold C, Ristova PP, Wenzhoefer F, Dittmar T, Boetius A (2013) How deep-sea wood falls 524 sustain chemosynthetic life. Plos One 8: e53590

526 Canals M, Puig P, de Madron XD, Heussner S, Palanques A, Fabres J (2006) Flushing submarine 527 canyons. Nature 444: 354-357

528

529 Chávez-Villalba J, Soyez C, Huvet A, Gueguen Y, Lo C, Moullac GL (2011) Determination of 530 gender in the Pearl Oyster Pinctada margaritifera. J Shellfish Res 30: 231-240 
532 Cunha MR, Matos FL, Génio L, Hilário A, Moura CJ, Ravara A, Rodrigues CF (2013) Are organic

533 falls bridging reduced environments in the deep sea? - Results from colonization experiments in the

534 Gulf of Cádiz. Plos One 8: e76688

535

536 Culliney IL, Turner RD (1976) Larval development of the deep-water wood boring bivalve,

537 Xylophaga atlantica Richards (Mollusca, Bivalvia, Pholadidae). Ophelia 15: 149-161

538

539 DeNiro MJ, Epstein S (1978) Influence of diet on the distribution of carbon isotopes in animals.

540 Geochim Cosmochim Ac 42: 495-506

541

542 Distel DL, Roberts SJ (1997) Bacterial endosymbionts in the gills of the deep-sea wood-boring

543 bivalves Xylophaga atlantica and X. washingtona. Biol Bull 192: 253-261

544

545 Distel DL, Beaudoin DJ, Morrill W (2002a) Coexistence of multiple proteobacterial endosymbionts

546 in the gills of the wood-boring bivalve Lyrodus pedicellatus (Bivalvia : Teredinidae). Appl Environ

547 Microbiol 68: 6292-6299

548

549 Distel DL, Morrill W, MacLaren-Toussaint N, Franks D, Waterbury J (2002b) Teredinibacter

550 turnerae gen. nov., sp. nov., a dinitrogen-fixing, cellulolytic, endosymbiotic gamma-proteobacterium

551 isolated from the gills of wood-boring molluscs (Bivalvia : Teredinidae). Int J Syst Evol Microbiol

$552 \quad 52: 2261-2269$

553

554 Distel DL, Amin M, Burgoyne A, Linton E, Mamangkey G, Morril W, Nove J, Wood N, Yang J

555 (2011) Molecular phylogeny of Pholadoidea Lamarck, 1809 supports a single origin for xylotrophy

556 (wood feeding) and xylotrophic bacterial endosymbiosis in Bivalvia. Mol Phylogenet Evol 61: 54-70 557

558 Duperron S, Nadalig T, Caprais J-C, Sibuet M, Fiala-Médioni A, Amann R, Dubilier, N (2005) Dual

559 symbiosis in a Bathymodiolus sp. mussel from a methane seep on the Gabon continental margin

560 (Southeast Atlantic): 16S rRNA phylogeny and distribution of the symbionts in gills. Appl Environ

561 Microbiol 71: 1694-1700

562

563 Duperron S, Pottier M-A, Leger N, Gaudron SM, Puillandre N, Le Prieur S et al (2013) A tale of two

564 chitons: is habitat specialisation linked to distinct associated bacterial communities? FEMS

565 Microbiol Ecol 83: 552-67 
567 Fagervold SK, Romano C, Kalenitchenko D, Borowski C, Nunes-Jorge A, Martin D, Galand, PE

568 (2014) Microbial communities in sunken wood are structured by wood-boring bivalves and location

569 in a submarine canyon. Plos One 9: e96248

570

571 Gaudron SM, Pradillon F, Pailleret M, Duperron S, Le Bris N, Gaill F (2010) Colonization of

572 organic substrates deployed in deep-sea reducing habitats by symbiotic species and associated fauna.

573 Mar Environ Res 70: 1-12

574

575 Gaudron SM, Demoyencourt E, Duperron S (2012) Reproductive traits of the cold-seep symbiotic mussel Idas modiolaeformis: gametogenesis and larval biology. Biol Bull 222: 6-16

578 Génio L, Rodrigues CF, Guedes IF, Almeida H, Duperron S, Hilário A (2015) Mammal carcasses

579 attract a swarm of mussels in the deep Atlantic: insights into colonization and biogeography of a

580 chemosymbiotic species. Mar Ecol 36: 71-81

581

582 Haga T, Kase T (2013) Progenetic dwarf males in the deep-sea wood-boring genus Xylophaga

583 (Bivalvia: Pholadoidea). J Mollus Stud 79: 90-94

584

585 FAO (2002) FISAT-II, Software Version 1.1.2. FAO-ICLARM Stock Assessment Tools, Rome.

586 http://www.fao.org/fishery/topic/16072/en

587

588 Hilário A, Metaxas A, Gaudron SM, Howell KL, Mercier A, Mestre NC, Ross RE, Thurnherr AR, 589 Young CM (2015) Estimating dispersal distance in the deep sea: challenges and applications to 590 marine reserves. Front Mar Sci. doi10.3389/fmars.2015.00006

592 Jablonski D, Lutz R (1983) Larval ecology of marine benthic invertebrates - Paleobiological

593 implications. Biol Rev Camb Philos Soc 58: 21-89

594

595 Knudsen J (1961) The bathyal and abyssal Xylophaga (Pholadidae, bivalvia). Danish Science Press

596 Ltd., Copenhagen

597 
598 Laming SR, Duperron S, Gaudron SM, Cunha MR (2014) Settled, symbiotic then sexually mature: 599 adaptive developmental anatomy in the deep-sea, chemosymbiotic mussel Idas modiolaeformis. Mar

600 Biol 161: 1319-1333

601

602 Laming SR, Duperron S, Gaudron SM, Hilário A, Cunha MR (2015) Adapted to change: the rapid 603 development of symbiosis in newly settled, fast-maturing chemosymbiotic mussels in the deep sea.

604 Mar Environ Res 112: 100-112

605

606 Manz W, Amann R, Ludwig W, Wagner M, Schleifer K-H (1992) Phylogenetic

607 oligodeoxynucleotide probes for the major subclasses of Proteobacteria: problems and solutions. Syst 608 Appl Microbiol 15: 593-600 609

610 Minagawa M, Wada E (1984) Stepwise enrichment of ${ }^{15} \mathrm{~N}$ along food chains: further evidence and 611 the relation between $\mathrm{d}^{15} \mathrm{~N}$ and animal age. Geochim Cosmochim Ac 48: 1135-1140

612

613 Nishimoto A, Mito S, Shirayama Y (2009) Organic carbon and nitrogen source of sunken wood 614 communities on continental shelves around Japan inferred from stable isotope ratios. Deep-Sea Res 615 56: $1683-1688$

617 Ockelmann KW, Dinesen GE (2011) Life on wood - the carnivorous deep-sea mussel Idas argenteus 618 (Bathymodiolinae, Mytilidae, Bivalvia). Mar Biol Res 7: 71-84

620 O'Connor RM, Fung JM, Sharp KH, Benner JS, McClung C, Cushing S, et al. (2014) Gill bacteria 621 enable a novel digestive strategy in a wood-feeding mollusk. Proc Natl Acad Sci USA 111: e5096622104

623

624 Olu K, Cordes EE, Fisher CR, Brooks JM, Sibuet M, Desbruyères D (2010) Biogeography and 625 potential exchanges among the Atlantic equatorial belt cold-seep faunas. Plos One 5: e11967. 626 doi:10.1371/journal.pone.0011967

628 Purchon RD (1941) On the biology and relationships of the lamellibranch Xylophaga dorsalis 629 (Turton). J Mar Biol Assoc UK 25: 1-39 
632 Richards HG (1942) Xylophaga atlantica, new species. The Nautilus 56: 68

633

634 Rodrigues CF, Laming SR, Gaudron SM, Oliver G, Le Bris N, Duperron S (2015) A sad tale: has the 635 small mussel Idas argenteus lost its symbionts? Biol J Linn Soc 114: 398-405

637 Romano C, Voight JR, Company JB, Plyuscheva M, Martin D (2013) Submarine canyons as the 638 preferred habitat for wood-boring species of Xylophaga (Mollusca, Bivalvia). Prog Oceanogr 118: $639 \quad 175-187$

640

641 Romano C, Voight JR, Pérez-Portela R, Martin D (2014) Morphological and genetic diversity of the 642 wood-boring Xylophaga (Mollusca, Bivalvia): new species and records from deep-sea Iberian 643 canyons. Plos One 9: e102887

645 Romey W, Castro K, Dealteris J, Bullock R (1991) Recruitment in the deep-sea wood-boring bivalve 646 Xylophaga atlantica Richards. Veliger 34: 14-20 647

648 Romey W, Bullock R, Dealteris J (1994) Rapid growth of a deep-sea wood-boring bivalve. Cont 649 Shelf Res 14: 1349-1359

651 Rouse GW, Goffredi SK, Vrijenhoek RC (2004) Osedax: bone-eating marine worms with dwarf 652 males. Science 305: 668-671

653

654 Santerre C, Sourdaine P, Marc N, Mingant C, Robert R, Martinez A-S (2013) Oyster sex

655 determination is influenced by temperature - First clues in spat during first gonadic differentiation 656 and gametogenesis. Comp Biochem Phys A 165: 61-69

658 Sipe AR, Wilbur AE, Cary SC (2000) Bacterial symbiont transmission in the wood-boring shipworm 659 Bankia setacea (Bivalvia: Teredinidae). Appl Environ Microbiol 66: 1685-1691 660

661 Szafranski KM, Gaudron SM, Duperron S (2014) Direct evidence for maternal inheritance of 662 bacterial symbionts in small deep-sea clams (Bivalvia: Vesicomyidae). Naturwissenschaften 101: 663 373-383 664 
665 Szafranski KM, Deschamps P, Cunha MR, Gaudron SM, Duperron S (2015) Colonization of plant

666 substrates at hydrothermal vents and cold seeps in the northeast Atlantic and Mediterranean and

667 occurrence of symbiont-related bacteria. Front Microbiol 6: 162. doi: 10.3389/fmicb.2015.00162 668

669 Thiel M, Gutow L (2005) The ecology of rafting in the marine environment. II. The rafting

670 organisms and community. Oceanogr mar biol 43: 279-418

671

672 Turner R (1973) Wood-boring bivalves, opportunistic species in the deep sea. Science 180: $1377-$ 6731379

674

675 Turner R (2002) On the subfamily Xylophagainae (Family Pholadidae, Bivalvia, Mollusca). Bull 676 MusComp Zool 157: 223-307

677

678 Tyler PA, Young CM, Dove F (2007) Settlement, growth and reproduction in the deep-sea wood679 boring bivalve mollusc Xylophaga depalmai. Mar Ecol Prog Ser 343: 151-159

680

681 Voight JR (2008) Deep-sea wood-boring bivalves of Xylophaga (Myoida: Pholadidae) on the 682 continental shelf: a new species described. J Mar Biol Assoc UK 88: 1459-1464 683

684 Voight JR (2015) Xylotrophic bivalves: aspects of their biology and the impacts of humans. J Mollus 685 Stud 81: 175-186

686

687 Voight JR, Segonzac M (2012) At the bottom of the deep blue sea: a new wood-boring bivalve 688 (Mollusca, Pholadidae, Xylophaga) from the Cape Verde Abyssal Plain (subtropical Atlantic). 689 Zoosystema 34: 171-180 690

691 Wallner G, Amann R, Beisker W (1993) Optimizing fluorescent in situ hybridization with 692 rRNA-targeted oligonucleotide probes for flow cytometric identification of microorganisms. 693 Cytometry 14: 136-143

694

695 Waterbury JB, Calloway CB, Turner RD (1983) A cellulolytic nitrogen-fixing bacterium cultured 696 from the gland of Deshayes in shipworms (Bivalvia: Teredinidae). Science 221: 1401-1403 697 
698 Williams ST, Reid DG (2004) Speciation and diversity on tropical rocky shores: a global phylogeny 699 of snails of the genus Echinolittorina. Evolution 58: 2227-2251

701 Young CM, Emson RH, Rice ME, Tyler PA (2013) A paradoxical mismatch of fecundity and 702 recruitment in deep-sea opportunists: cocculinid and pseudococculinid limpets colonizing vascular 703 plant remains on the Bahamian Slope. Deep-Sea Res 92: 36-45 
Table 1 Mean stable $\mathrm{C}$ and $\mathrm{N}$ isotope values ( $\pm \mathrm{SD}$ ) and $\mathrm{C} / \mathrm{N}$ ratios for female and associated dwarf male Xylophaga atlantica

collected after $414 \mathrm{~d}$ at $2279 \mathrm{~m}$ depth at Mid-Atlantic Ridge. Values for one co-occurring polychaete added as positive control.

\begin{tabular}{|c|c|c|c|c|}
\hline Samples & $n$ & $\delta^{13} \mathrm{C}$ & $\delta^{15} \mathrm{~N}$ & $\mathrm{C} / \mathrm{N}$ \\
\hline Wood & 3 & $-23.1( \pm 0.1)$ & - & $159.6( \pm 17.3)$ \\
\hline $\begin{array}{l}\text { Female autonomous wood- } \\
\text { borers }\end{array}$ & 3 & - & $4.6( \pm 0.5)$ & $5.3( \pm 0.3)$ \\
\hline $\begin{array}{l}\text { Female autonomous wood- } \\
\text { borers acidified }\end{array}$ & 3 & $-21.7( \pm 0.3)$ & - & - \\
\hline Dwarf males acidified & $\begin{array}{l}30 \\
\text { (pool) }\end{array}$ & -20.2 & 6.4 & 3.8 \\
\hline Amphinomid polychaete & 1 & -19.9 & 8.0 & 4.4 \\
\hline
\end{tabular}

718 


\section{Figure captions}

722 Fig. 1 SEMs of Xylophaga atlantica females bearing dwarf males. a) Prodissoconch I (Pdl)

723 with edge marked by arrow (scale bar $50 \mu \mathrm{m}$ ); b) female with attached dwarf males

724 (outlined) (scale bar $1 \mathrm{~mm}$ ); c) dwarf males from b) magnified (scale bar $500 \mu \mathrm{m}$ )

726 Fig. 2 Microscopic images of autonomous wood-boring females Xylophaga atlantica ( 3

$727 \mathrm{~mm} \mathrm{SL}$ ). a) transverse section of tissues stained with haematoxylin/eosin (HE) highlighting

728 female reproductive features, mature oocytes on right and gill on left, with possible

729 spawned oocytes (scale bar $500 \mu \mathrm{m}$ ); inset shows mature oocytes at higher magnification

730 (scale bar $50 \mu \mathrm{m}$ ); b) fluorescence in situ hybridization (FISH) image showing bright green

731 gill (probe EUB-338 [Cy-3]) and DAPI-stained nuclei of gill filament and germinal cells. Note

732 absence of bacterial signal in acini in germinal cells and oocytes compared to positive

733 control in gill (arrow) (scale $50 \mu \mathrm{m}$ ); c) HE-stained section showing gill filament with pink

734 ciliated region (arrow) and non-ciliated region (purple); also showing oocytes, germinal cells

735 and spawned oocytes (scale bar $50 \mu \mathrm{m}$ ); d) FISH image showing overlapping EUB-338

736 (Cy-3; green) and Gam-42 (Cy-5; red) staining (white arrow) and DAPI-stained nuclei in gill

737 (blue); note bacterial signal in non-ciliated gill region (scale bar $50 \mu \mathrm{m}$ ); be?, spawned

738 oocyte; gc, germinal cell; gl, gill filament; ov, mature oocyte

740 Fig. 3 Microscopic images of autonomous wood-boring males Xylophaga atlantica ( $2 \mathrm{~mm}$

741 SL). a) transverse section of tissues stained with haematoxylin/eosin (HE) highlighting

742 male reproductive features and gill filament of two types: ciliated (blue arrow) and non-

743 ciliated (red arrow); b) fluorescence in situ hybridization image showing overlapping EUB-

744338 (Cy-3; red) and Gam-42 (Cy-5; green) yielding few bright dots (white arrow) and DAPI-

745 stained nuclei in gill (blue arrow). Scale bars $50 \mu \mathrm{m}$; spc, spermatocyte; gl, gill filament 746

747 Fig. 4 Microscopic images of dwarf males Xylophaga atlantica ( 0.5 mm SL). a) longitudinal 748 serial section of tissues stained with haematoxylin/eosin highlighting male reproductive 749 features (scale bar $200 \mu \mathrm{m}$ ); b) and c) high magnification of a closely similar LR-White 750 semi-thin sections (300 nm); b) section stained with Toluidine blue showing two gill 751 filaments with ciliated region (arrow) (scale bar $15 \mu \mathrm{m}$ ); c) section hybridized by 752 fluorescence, where Gam-42 (Cy-3) yield some bright green dots in gill (arrow) and DAPI- 
753 stained nuclei (scale bar $15 \mu \mathrm{m}$ ); ft, foot; gl, gill filament; spc, spermatocyte; sg,

754 spermatogonia; msp, mature spermatozoa; re, rectum; te, testis; pa, posterior adductor 755 muscle

756

757 